\title{
日本臨床麻酔学会第19回大会シンポジウム
}

\section{プロポフォールの未来は（ICUでの使用を含めて） ICUにおけるプロポフォール使用の問題点}

\author{
足立健彦*
}

\section{Iはじめに}

1999 年 3 月よりプロポフォールの効能として「集 中治療における人工呼吸中の鎮静」が承認され，日 本でも ICUにおけるプロポフォールの使用が開始さ れた。 承認されたばかりの効能に関して, その未来 を論ずるのは大変困難であるが, 議論の一助とする ため，本稿では現在までに報告されているICUにお ける鎮静薬としてのプロポフォールの利点及び欠点 について文献的にまとめた.

\section{IIICUでの鎮静薬としてのプロポフォールの利点}

ICUにおける鎮静薬としてのプロポフォールに関 する最初の文献的な報告は 1987 年にみられ, 大量 フェンタニル麻酔による冠動脈バイパス術後の患者 を対象に，プロポフォール持続投与とミダゾラム間 歇的投与の比較検討を行ない，プロポフォールの方 が鎮静終了から抜管までの時間が有意に短く，目標 鎮静レベルであるラムゼイスコア 3 (言葉による指示 に反応）に保った時間も, 有意に長かった ${ }^{1)}$ 。この最 初の論文からすでに，プロポフォールの最大の利点 である鎮静深度の調節性のよさ，及び投与中止後の 意識の回復と覚醒のすみやかさのデータが示されて いることになる。日本におけるICUでの鎮静のため のプロポフォールの使用法は, 気管挿管による気道 確保を前提とする使用量として $0.3 \mathrm{mg} \cdot \mathrm{kg}^{-1} \cdot \mathrm{h}^{-1}$ か ら $3 \mathrm{mg} \cdot \mathrm{kg}^{-1} \cdot \mathrm{h}^{-1}$ の範囲が推奨されている。われ

*京都大学医学部附属病院集中治㙩部
われの施設ではラムゼイスコア 3 の鎮静レベルを目 標にプロポフォールを投与し，必要に応じて投与量 を上げて鎮静深度を深くしている，鎮静しベルを一 時的に深くした後に元の鎮静レベルに戻すのも短時 間ですみ，例えば投与量を増加して施行した気管支 ファイバーの後でも, 家族との面会時に筆談等によ るコミュニケーションも可能になる．このように鎮 静深度の調節性のよさは, 実際にプロポフォールを 用いて鎮静を行なうと利点として実感される。

その他の利点として，ストレスホルモンの抑制 ${ }^{2)}$, 制吐作用 ${ }^{3)}$, 抗掻痒作用 ${ }^{4)}$ があげられる. 脳代謝抑制, 脳圧抑制作用，抗痙攣作用もあり，チオペンタール 療法の代わりに用いることも可能であるが ${ }^{5}$, 安全 のためには投与量が多くなりすぎないように十分な 注意が必要であろう。COPD患者において気管支拡 張作用の存在も示唆されている ${ }^{6}$.

\section{IIIICUでの鎮静薬としてのプロポフォールの欠点}

プロポフォール投与時の循環抑制は, 麻酔薬とし てプロポフォール使用経験の豊富な医師にはよく知 られていると思われるが，ICUではボーラス投与を 行なわず，投与量及び投与速度を調節することで対 処できる。

プロポフォールは $1 \%$ 溶液であり，厳密な水分出 納の管理を要する患者においては投与液量の多さが 負担となり得るのも欠点の一つと考えられる。この 点に関しては，プロポフォールの投与液量を水分出 納の計算に加える，また脂肪製剂であるのでそのカ ロリーも計算に加えて管理する以外に方法はない. 
欧米で使用可能な $2 \%$ 溶液が今後日本でも発売され れば投与液量の問題は半減させることができるが, 現時点では日本で $2 \%$ 溶液が発売される予定はない.

プロポフォールは脂肪製荗であるので細菌に污染 されると増殖するおそれがあるが，一方でエマルジョ ン破壊のおそれがあるため細菌フィルターは使用不可 能である. 従って, 厳密な無菌操作に加えて, 取扱上 の注意として 12 時間ごとにシリンジ及び回路の交換 が義務づけられている．污染したプロポフォールを介 した感染例も報告されており ${ }^{7)}$, 無菌操作に加えて, 繁雑ではあるが 12 時間を超える場合のシリンジ及び 回路の交換は遵守する必要がある，正しい使用法を守 れば, ICUでの鎮静で污染したプロポフォールによる 感染の危険性はきわめて低い ${ }^{8)}$.

プロポフォールには鎮痛作用がないので，他の鎮 痛手段の併用は必須である。われわれの施設では, 鎮痛を必要とする患者には, 局所麻酔薬と麻薬の硬 膜外カテーテルからの持続投与か, 麻薬の持続静脈 内投与で十分な鎮痛を計っている。鎮痛が不十分で 不穏状態になっているのに，プロポフォールの鎮静 深度を上げて対処するようなことのないよう，注意 深い鎮痛効果の判定が必要になる．鎮静薬剤が鎮痛 効果を持たないのはプロポフォールに限ったことで はなく，鎮痛効果を併せ持ち，かつ鎮静効果の調節 性に優れた鎮静薬剤は現時点では存在しない. 将来 このような薬凨が出現してくると，他に鎮痛法を講 じなければならない点はプロポフォールの大きな欠 点として認識されるようになる可能性がある.

プロポフォールを鎮静目的で長期に使用している と, 同じ使用量では効果が低くなり, 投与量を増加 させなければならなくなる現象はときに経験され る。この点について血中濃度を測定して検討した報 告によると, 同じ投与量でも血中濃度が低下してい る，すなわちプロポフォールのクリアランスが増加 している例と血中濃度は維持されているのに効果が 低下している例(薬片耐性) とが存在する ${ }^{9}$.

プロポフォールは主に肝蔵で代謝され，腎臓で排 泄される.ICUでよくみられるような肝機能あるい
は腎機能障害患者への使用には注意を要すると考え られるが，文献的には肝硬変患者，腎不全患者への 使用で特に薬物動態に変化は認められていない 10), 11). ICUでよく行なわれる持続血液濾過透析によって も，導入時に一時的に血中濃度が低下することが多 い以外には，実質的な影響はない ${ }^{12}$.

プロポフォール投与によって高尿酸尿症が起こる という報告がある ${ }^{13)}$ ，尿が白濁し，尿酸結晶によっ て尿道バルーンが閉塞したという事例も報告されて おり ${ }^{14)}$ ，欠点の一つと考元られるが，高尿酸血症の 患者にとつては利点になり得る.

プロポフォールに起因すると推定される膵炎の報 告も散見され，なかには死亡例も報告されている ${ }^{15)}$. プロポフォールを長期投与すると高トリグリセリド 血症が生じ，高トリグリセリド血症は膵炎の原因に なり得るが，必ずしも高トリグリセリド血症を伴わ ない膵炎も報告されている ${ }^{16)}$.

麻酔においては, 小児を対象とした臨床試験が行な われていないためプロポフォールの小児への使用は 安全性が確立していないとされているが, 集中治療 における鎮静では小児へは使用しないことが望まし いとされている，小児に使用して，代謝性アシドー シスと徐脈性不整脈を生じて死亡し，プロポフォー ルとの因果関係が疑われた初期の症例報告 ${ }^{17)}$ が存在 するためである。その後も同様の症例報告が散見さ れる ${ }^{18), 19)}$ 。これらの報告に共通していることはプロ ポフォールの投与量が著しく多く，全身麻酔での使 用量に匹敵する量を数日間にわたって投与している ことである。これらの報告に対しては批判もあり ${ }^{20)}$, 小児に対する正しい投与量が提案されている ${ }^{21)}$. い ずれにしても鎮静薬剤としてのプロポフォールが小 児に安全に使用可能か否かは大変重要な問題である. 今後，大規模な臨床調査を施行すべきであるという 意見も再三発表されている ${ }^{22,23)}$ ので，今後の推移を 見守りたい.

\section{IV おわりに}

本原稿投稿時点で, 日本ではプロポフォールは麻 
酔薬として使用可能になって約 4 年, 集中治療にお ける鎮静薬剤としてはまだ 8 カの経験しかない. 海外でも高だか 10 年少しの使用経験しかない薬剤で ある．集中治療中の鎮静薬剤として，プロポフォー ルの調節性のよさが大変に優れたものであることは 間違いないが, 今後とも気道確保, 使用量及び期間, 污染防止の注意等を遵守し, 国内外の副作用報告に 注意を払って安全で有効な使い方を行なっていく必 要がある。

\section{参考文献}

1) Grounds R, Lalor J, Lumley J, et al. : Propofol infusion for sedation in the intensive care unit : preliminary report. Br Med J $294: 397 \sim 400,1987$

2) Plunkett JJ, Reeves JD, Ngo L, et al. : Urine and plasma catecholamine and cortisol concentration after myocardial revascularization modulation by continuous sedation. Anesthesiology $86: 785 \sim 796,1997$

3) Gan TJ, Ei-Molem H, Ray J, et al. : Patient-controlled antiemesis. Anesthesiology $90: 1564 \sim 1570,1999$

4）長沼利佳, 土田英昭, 岡沼水緒子ほか : くも膜下腔モル ヒネ投与後の掻痒感に対するプロポフォールの効果. 麻 酔 $47: 562 \sim 565,1998$

5）池田寿昭：チオペンタール療法の代わりとして. ICU \& CCU $22: 233 \sim 239,1998$

6) Conti G, Dell'Utri D, Vilardi V, et al. : Propofol induces bronchodilatation in mechanically ventilated chronic obstructive pulmonary disease (COPD) patients. Acta Anaesth Scand $37: 105 \sim 109,1993$

7) Kuerhnert MJ, Webb RM, Jochimsen EM, et al. : Staphylococcus aureus bloodstream infections among patients undergoing electroconvulsive therapy traced to breaks in infection control and possible extrinsic contamination by propofol. Anesth Analg $85: 420 \sim 425,1997$

8) Webb SA, Roberts B, Breheny FX, et al. : Contamination of propofol infusions in the intensive care unit : incidence and clinical significance. Anaesth Intensive Care $26: 162 \sim 164$, 1998

9) Buckley PM : Propofol in patients needing long-term sedation in intensive care : an assessment of the development of tolerance. Intensive Care Medicine 23 : 969 974, 1997

10) Ickx B, Cockshott ID, Barvais L, et al. : Propofol infusion for induction and maintenance of anaesthesia in patients with end-stage renal disease. Br J Anaesth $81: 854 \sim$ 860, 1998

11) Servin F, Cockshott ID, Farinotti R, et al. : Pharmacokinetics of propofol infusions in patients with cirrhosis. $\mathrm{Br}$ J Anaesth $65: 177 \sim 183,1990$

12) Eddeleston JM, Pollard BJ, Blades JF, et al. : The use of propofol for sedation of critically ill patients undergoing haemodiafiltration. Intensive Care Medicine $21: 342 \sim 347$, 1995

13) Masuda A, Asahi T, Sakamaki M, et al. : Uric acid excreion increases during propofol anesthesia. Anesth Analg $85: 144 \sim 148,1997$

14）久保周敬, 杉岡信吾, 安留輝之ほか: プロポフォール 麻酔に起因すると考えられる尿道カテーテル閉塞の 1 症 例. 日歯麻誌 $26 ： 103 \sim 105.1998$

15) Leisure GS, O'Flaherty J, Green L, et al. : Propofol and postoperative pancreatitis. Anesthesiology $84: 224 \sim 227,1996$

16) Kumar AN, Schwartz DE, Lim KG : Propofol-induced pancreatitis recurrence of pancreatitis after rechallenge. Chest 115: 1198 1199, 1999

17) Parke TJ, Stevens JE, Rice ASC, et al. : Metabolic acidosis and fatal myocardial failure after propofol infusion in children : five case reports. Br Med J 305 : 613 616, 1992

18) Strickland RA, Murray MJ : Fatal metabolic acidosis in a pediatric patient receiving an infusion of propofol in the intensive care unit : Is there a relationship? Crit Care Med $23: 405 \sim 409,1995$

19) Cray SH, Robinson BH, Cox PN : Lactic acidemia and bradyarrhythmia in a child sedated with propofol. Crit Care Med 26 : 2087 2092, 1998

20) Reed MD, Blumer JL : Propofol bashing : the time to stop is now! Crit Care Med 24:175 177, 1996

21) Reed MD, Yamashita TS, Marx CM, et al. : A pharmacokinetically based propofol dosing strategy for sedation of the critically ill, mechanically ventilated pediatric patient. Crit Care Med $24: 1473 \sim 1481,1996$

22) Hatch DJ : Propofol in paediatric intensive care. Br J Anaesth $79: 274 \sim 275,1997$

23) Hatch DJ : Propofol-infusion syndrome in children. Lancet $353: 1117 \sim 1118,1999$

\author{
著者連絡先 足立健彦 \\ 于 606-8507 京都市左京区聖護院川原町 54 \\ 京都大学医学部附属病院集中治療部
}

